\title{
Production and carbonate dynamics of Halimeda incrassata (Ellis) Lamouroux altered by Thalassia testudinum Banks and Soland ex König
}

\author{
Savanna C. Barry a,*, Thomas K. Frazer ${ }^{\mathrm{a}, \mathrm{b}}$, Charles A. Jacoby ${ }^{\mathrm{c}}$ \\ a Fisheries and Aquatic Sciences Program, 7922 NW 71st Street, University of Florida, Gainesville, FL 32653-0600, USA \\ b School of Natural Resources and Environment, P.O. Box 116455, University of Florida, Gainesville, FL 32611-6455, USA \\ c Department of Soil and Water Science, University of Florida, P.O. Box 110510, Gainesville, FL 32611-0510, USA
}

\section{A R T I C L E I N F O}

\section{Article history:}

Received 29 January 2013

Received in revised form 13 March 2013

Accepted 15 March 2013

Available online 15 April 2013

\section{Keywords:}

Calcareous algae

Calcification

Ocean acidification

Photosynthesis

Respiration

Seagrass

\begin{abstract}
A B S T R A C T
Ocean acidification poses a serious threat to a broad suite of calcifying organisms. Scleractinian corals and calcareous algae that occupy shallow, tropical waters are vulnerable to global changes in ocean chemistry because they already are subject to stressful and variable carbon dynamics at the local scale. For example, net heterotrophy increases carbon dioxide concentrations, and $\mathrm{pH}$ varies with diurnal fluctuations in photosynthesis and respiration. Few researchers, however, have investigated the possibility that carbon dioxide consumption during photosynthesis by non-calcifying photoautotrophs, such as seagrasses, can ameliorate deleterious effects of ocean acidification on sympatric calcareous algae. Naturally occurring variations in the density of seagrasses and associated calcareous algae provide an ecologically relevant test of the hypothesis that diel fluctuations in water chemistry driven by cycles of photosynthesis and respiration within seagrass beds create microenvironments that enhance macroalgal calcification. In Grape Tree Bay off Little Cayman Island BWI, we quantified net production and characterized calcification for thalli of the calcareous green alga Halimeda incrassata growing within beds of Thalassia testudinum with varying shoot densities. Results indicated that individual $H$. incrassata thalli were $\sim 6 \%$ more calcified in dense seagrass beds. On an areal basis, however, far more calcium carbonate was produced by H. incrassata in areas where seagrasses were less dense due to higher rates of production. In addition, diel $\mathrm{pH}$ regimes in vegetated and unvegetated areas within the lagoon were not significantly different, suggesting a high degree of water exchange and mixing throughout the lagoon. These results suggest that, especially in well-mixed lagoons, carbonate production by calcareous algae may be more related to biotic interactions between seagrasses and calcareous algae than to seagrass-mediated changes in local water chemistry.
\end{abstract}

(c) 2013 Elsevier B.V. All rights reserved.

\section{Introduction}

Acidification of the world's oceans generated by a global rise in carbon dioxide $\left(\mathrm{CO}_{2}\right)$ emissions is a major ecological concern (Kleypas et al., 1999; National Research Council, 2010; Skirrow and Whitfield, 1975). As atmospheric $\mathrm{CO}_{2}$ is absorbed by seawater, stoichiometric changes in the carbonic acid system lead to lower concentrations of carbonate ions $\left(\mathrm{CO}_{3}^{2-}\right)$ and higher concentrations of hydrogen ions $\left(\mathrm{H}^{+}\right)$, which translates into lower $\mathrm{pH}$ values (Doney et al., 2012; Guinotte and Fabry, 2008; McClendon, 1917, 1918). These changes in concentrations of $\mathrm{CO}_{3}^{2-}$ and $\mathrm{H}^{+}$potentially interfere with sequestration of calcium carbonate $\left(\mathrm{CaCO}_{3}\right)$ by a broad suite of marine organisms that use this compound to form skeletons, shells, otoliths, statoliths and other key structures (Hoegh-Guldberg et al., 2007; Kleypas et al., 1999; Kroeker et al., 2010). In contrast, seagrasses and other photosynthetic organisms may experience an increase in production as $\mathrm{CO}_{2}$ is absorbed

\footnotetext{
* Corresponding author. Tel.: +1 8043056014.

E-mail addresses: savanna.barry@ufl.edu (S.C. Barry), frazer@ufl.edu (T.K. Frazer), cajacoby@ufl.edu (C.A. Jacoby).
}

by coastal waters, especially in those areas where dissolved inorganic carbon is presently limiting (e.g., Palacios and Zimmerman, 2007). Healthier seagrasses may provide enhanced ecosystem services, including greater uptake and cycling of nutrients, more extensive habitat, improved stabilization of sediments and increased carbon sequestration (Duarte et al., 2010; Fourqurean et al., 2012; Waycott et al., 2009). Moreover, seagrasses may serve to mediate and possibly ameliorate the deleterious effects of ocean acidification on a large number of sympatric species by consuming $\mathrm{CO}_{2}$ during photosynthesis (Kleypas et al., 2011; Manzello et al., 2012; Semesi et al., 2009a,b; Unsworth et al., 2012).

In the tropics, seagrasses often coexist with ecologically important, calcareous photoautotrophs (Dahlgren and Marr, 2004; Fong and Paul, 2011; Littler and Littler, 1988, 1994). Calcareous green algae, such as Halimeda spp., are common cohabitants (Littler, 1976; Littler and Littler, 1988, 1994), and such species perform important ecological functions. For example, photosynthetic production by Halimeda incrassata (Ellis) Lamouroux 1812 in Florida Bay was 20\% of that attributed to the dominant seagrass, Thalassia testudinum Banks and Soland ex König 1805 (Davis and Fourqurean, 2001). In addition, 
several species of Halimeda serve as a key food source and are, in fact, a preferred food of several coral reef fishes (Mantyka and Bellwood, 2007; Overholtzer and Motta, 1999). More importantly, however, Halimeda spp. and other calcareous algae play critical roles in the formation of calcium carbonate $\left(\mathrm{CaCO}_{3}\right.$; Nelson, 2009; Vroom et al., 2003). For example, Halimeda spp. produce $\mathrm{CaCO}_{3}$ at rates nearly equal to coral reefs, and these algae can account for 35-45\% of carbonates generated in shallow tropical waters (Lee and Carpenter, 2001; Milliman and Droxler, 1996; Nelson, 2009; Vroom et al., 2003). Furthermore, Halimeda spp. are known to be important producers of coarse-grained sediments (Freile et al., 1995), and spalling of calcified plates is a primary mechanism by which sand is formed in tropical seas (Littler, 1976; Littler and Littler, 1988, 1994). Thus, calcareous algae and their interactions with seagrasses represent important components of tropical systems.

In oligotrophic, tropical waters, seagrasses and calcareous algae can compete, with dominance leading to greater abundance of seagrasses (Davis and Fourqurean, 2001; Williams, 1987, 1990; Zieman and Wetzel, 1980). In contrast, positive interactions whereby seagrasses promote the existence and co-occurrence of key calcareous algae by raising $\mathrm{pH}$, altering the stoichiometry of calcification, and enhancing release of hydrogen ions formed during this process have not been examined in an open system (Semesi et al., 2009a). In mesocosm experiments, diel fluctuations in water chemistry within seagrass beds driven by cycles of photosynthesis and respiration demonstrated a potential for seagrasses to create microenvironments that are conducive to the calcification of algae (Semesi et al., 2009a). Sites with varying densities of both seagrasses and rhizophytic, calcareous algae provide opportunities to test this hypothesis in situ.

In this study, sites with varying densities of T. testudinum and H. incrassata were identified in Grape Tree Bay off Little Cayman Island. Our objective was to elucidate significant interactions between $T$. testudinum and $H$. incrassata by measuring production of $T$. testudinum and production and calcification of $H$. incrassata. Measures of key water quality parameters provided data to assess potential causes of variations in production or calcification. Two hypotheses were tested: 1) T. testudinum and $H$. incrassata would be more productive at sites with lower densities of the other photoautotroph and 2) calcification of $H$. incrassata would increase at sites with denser T. testudinum.

\section{Materials and methods}

\subsection{Study site}

Grape Tree Bay is a shallow lagoon on the north coast of Little Cayman Island, BWI. A mixed seagrass and calcareous algal assemblage extends offshore for approximately $60-100 \mathrm{~m}$ where it is bounded by a fringing reef. The fringing reef delineates the seaward edge of Grape Tree Bay, which spans approximately $1.6 \mathrm{~km}$ of shoreline. Based on data from a National Oceanic and Atmospheric Administration Integrated Coral Reef Observation Network (ICON) station located just outside the fringing reef, ocean temperature ranged from $28.0{ }^{\circ} \mathrm{C}$ to $30.6{ }^{\circ} \mathrm{C}$ and salinity averaged $35.8 \%$ (range 33.0 to $36.1 \%$ ) during June-August 2011, the period of this study.

\subsection{Densities of macrophytes and site selection}

To select sites with differing densities of $T$. testudinum and $H$. incrassata, benthic vegetation in Grape Tree Bay was surveyed within a systematic grid. Forty points along the shoreline were marked with GPS waypoints, and these points, which were separated by $10 \mathrm{~m}$, served as the origins for transects that ran offshore to the fringing reef. Along each transect, a $0.25-\mathrm{m}^{2}$ quadrat was placed at the 10 -m mark and also at every successive $10-\mathrm{m}$ mark. Thus, 6-10 quadrats were sampled along each transect depending on the distance between the shoreline and the fringing reef.
Within each quadrat, thalli of all algal taxa were counted. Subsequently, a $0.0625-\mathrm{m}^{2}$ subquadrat was thrown within each $0.25-\mathrm{m}^{2}$ quadrat. Within each subquadrat, shoots of all seagrass species were counted separately, with $T$. testudinum being the dominant species.

Sites for measurements of production for T. testudinum and production and calcification for $H$. incrassata were selected by comparing densities of shoots and thalli. The goal was to identify three treatments that spanned the natural gradient in Grape Tree Bay, i.e., 1) low density Halimeda combined with high density Thalassia (LHHT), 2) medium density Halimeda and Thalassia (MHMT), and 3) high density Halimeda combined with low density Thalassia (HHLT). The final densities bounding the triplicate sites allocated to each treatment were results generated by surveying 358 quadrats and subquadrats, with an additional constraint that no more than two replicate sites were located within $10 \mathrm{~m}$ of each other. At each experimental site, shoot and thalli counts were repeated to verify that densities were appropriate.

\subsection{Water quality measurements}

During the course of the field experiment, a YSI 600R data sonde with a YSI 650 MDS data logger was deployed at each of the nine treatment sites and at an additional three unvegetated sites for at least $24 \mathrm{~h}$. Temperature, salinity, dissolved oxygen, and $\mathrm{pH}$ were recorded at 30 -min intervals throughout each 24 -h period. Measurements were taken at a height of approximately $5 \mathrm{~cm}$ above the sediment to document conditions within the seagrass canopy, when seagrass was present.

\subsection{Field procedures, laboratory processing and calculation of metrics}

Two methods were used to distinguish new growth from existing tissue as a way to measure production for $T$. testudinum and $H$. incrassata. T. testudinum production was measured with a leaf marking technique (Zieman, 1974), wherein a heavy gauge needle was forced through all blades in a shoot just above their basal meristems and marked shoots were allowed to grow in situ. Thalli of $H$. incrassata were stained with Alizarin-S dye so that new, unstained tissue could be distinguished at the end of an in situ growth period (Davis and Fourqurean, 2001; Multer, 1988; Vroom et al., 2003; Wefer, 1980). When possible, 40 shoots and 25 thalli were marked within each experimental site.

After $7 \mathrm{~d}$, marked macrophytes were harvested. H. incrassata thalli were harvested by removing their basal holdfasts from the sediment. T. testudinum shoots were harvested at the node where the short shoot meets the rhizome so that the entire sheath was retained. Individual algal thalli and seagrass shoots were placed in separate, labeled bags and frozen prior to processing.

Individual T. testudinum shoots were rinsed in freshwater, scraped with a razor blade to remove epiphytic material, and briefly rinsed in freshwater again. Epiphytic material was discarded because the epiphyte load was very low and calcareous epiphytes were found to be insignificant contributors to the carbonate sediments of a neighboring island (Corlett and Jones, 2007). For each blade with a hole, new and old growth were separated by cutting through the hole with a razor blade. Unmarked blades were considered new growth. Old and new materials were placed in separate, tared borosilicate glass vials and dried at $50{ }^{\circ} \mathrm{C}$ to a constant weight. Dry weights of old material characterized the initial biomass of $T$. testudinum shoots. Dry weights of new material yielded direct measures of production for shoots of T. testudinum ( $\mathrm{mg}$ DW shoot ${ }^{-1} \mathrm{~d}^{-1}$ ). The quotients of new growth and initial weights represented standardized rates of production illustrating growth performance ( $m g$ DW new:mg DW old $d^{-1}$ ). Net areal production ( $\mathrm{mg} \mathrm{DW} \mathrm{m}^{-2} \mathrm{~d}^{-1}$ ) was calculated by multiplying production for shoots by the appropriate mean density of shoots (Davis and Fourqurean, 2001). 
Each $H$. incrassata thallus was rinsed with freshwater using the focused stream from a wash bottle to remove sand, debris, and epiphytic material. New, unstained plates and old, stained plates were separated, placed into different tared borosilicate glass vials, and dried at $50{ }^{\circ} \mathrm{C}$ to a constant weight. After dry weights were recorded, new and old $H$. incrassata plates were transferred into separate, preweighed, aluminum dishes, ashed for $3 \mathrm{~h}$ at $500{ }^{\circ} \mathrm{C}$, and allowed to cool before being weighed to determine quantities of inorganic carbon, i.e., $\mathrm{CaCO}_{3}$ (Davis and Fourqurean, 2001). Ashing was preferred because acidification can cause loss of organic content (Roberts et al., 1973) and ashing at $500{ }^{\circ} \mathrm{C}$ represents a reliable method for determining $\mathrm{CaCO}_{3}$ content of sediments (Byers et al., 1978; Hirota and Szyper, 1975; Radar and Grimaldi, 1961). For the purposes of this study, contributions from silicon and other trace elements that might have remained after ashing were considered negligible (Eisler, 2010). Organic content was estimated by subtracting the inorganic fraction from the total, pre-ashing dry weight of a sample. Dry weights of unstained plates ( $\mathrm{mg}$ DW thallus ${ }^{-1} \mathrm{~d}^{-1}$ ) were used as direct measures of total production, and they yielded estimates of net areal production ( $\mathrm{mg} \mathrm{DW} \mathrm{m} \mathrm{m}^{-2} \mathrm{~d}^{-1}$ ) when scaled by the appropriate densities. As a measure of relative production and growth performance, organic matter in new growth was standardized to the quantity of organic matter in the original thallus. In addition to measures of production, calcification was quantified for $H$. incrassata to evaluate influences mediated by $T$. testudinum. Calcification was characterized by the ratio of $\mathrm{CaCO}_{3}$ to organic matter because the photosynthetic activity of living, organic tissue is responsible for calcification of the thallus (Borowitzka and Larkum, 1976a, 1977; de Beer and Larkum, 2001). Estimates were calculated separately for entire thalli and the portion of each thallus representing new growth. In addition, $\mathrm{CaCO}_{3}$ contents expressed as proportions of the total dry weights of thalli provided an overall measure of calcification.

\subsection{Statistical analyses}

Statistically significant differences in water chemistry at experimental and unvegetated sites were assessed with multivariate permutation analyses of variance (PERMANOVAs; Anderson et al., 2008). Analyses were based on range standardized mean water temperatures, salinities, dissolved oxygen concentrations and hydrogen ion concentrations calculated over 30-min intervals throughout the 24-h periods. Due to anomalies caused by two days of bad weather, data from one MHMT site and one LHHT site were excluded from the analyses. In total, three PERMANOVAs were performed, with the first examining differences among treatments (LHHT, MHHT, HHLT and unvegetated sand) for all environmental data. Two other analyses examined differences among treatments for 1 ) hydrogen ion concentrations across full 24-h periods and 2) hydrogen ion concentrations during daytime periods in order to assess changes driven by photosynthesis.

Univariate analyses of variance (ANOVAs) were used to evaluate rates of production and calcification. Normality was evaluated with Anderson-Darling tests, and homoscedasticity was evaluated with Brown-Forsythe tests. If necessary, data were transformed to meet the assumptions. Areal production was analyzed with a one-way ANOVA that considered treatment (LHHT, MHMT and HHLT) as a fixed effect. Initial biomass of $T$. testudinum and $H$. incrassata and all other rates of production and calcification were analyzed using nested ANOVAs with treatment as a fixed effect and sites nested within treatments. Ryan-Einot-Gabriel-Welsch Q multiple comparisons were employed to discern differences among treatments. For unbalanced ANOVAs generated by differences in the number of marked and processed shoots or thalli, the Tukey-Kramer adjustment was applied to generate degrees of freedom for the post-hoc tests.

\section{Results}

\subsection{Densities of macrophytes and site selection}

The maximum shoot density of $T$. testudinum in Grape Tree Bay was greater than that of $H$. incrassata thalli by approximately an order of magnitude. Shoot density for $T$. testudinum ranged from 0 to 1900 shoots $\mathrm{m}^{-2}$, whereas density of $H$. incrassata thalli ranged from 0 to 246 thalli $\mathrm{m}^{-2}$. Sites for experimental marking of $T$. testudinum and $H$. incrassata were selected to span the density gradient in Grape Tree Bay and to ensure dispersion. Nine sites were chosen, with three replicate sites in each of three treatments (HHLT $=$ High Halimeda [164-184 thalli $\mathrm{m}^{-2}$ ], Low Thalassia [48-352 shoots $\mathrm{m}^{-2}$ ]; MHMT $=$ Medium Halimeda [96-112 thalli $\mathrm{m}^{-2}$ ], Medium Thalassia [6721120 shoots $\mathrm{m}^{-2}$ ]; and LHHT $=$ Low Halimeda $\left[8-24\right.$ thalli $\mathrm{m}^{-2}$ ], High Thalassia [1728-1888 shoots $\left.\mathrm{m}^{-2}\right]$ ). Overall, the nine sites spanned $265 \mathrm{~m}$ of the $1.6 \mathrm{~km}$ long bay, and replicate sites were separated by $10-252 \mathrm{~m}$.

\subsection{Water chemistry}

Mean DO concentrations and $\mathrm{pH}$ values increased throughout the daylight hours and decreased at night (Fig. 1). The highest mean DO concentrations (10.8 $\mathrm{mg} \mathrm{L}^{-1}$ ) were recorded during the day for the LHHT treatment sites (Fig. 1A), which would be expected given photosynthesis by T. testudinum. Also, as expected, sites where seagrass was less dense (including unvegetated sites) exhibited less pronounced diel variations in DO concentrations (Fig. 1A). Similarly, the dense seagrass treatment (LHHT) exhibited a higher mean pH during the day and a slightly lower mean $\mathrm{pH}$ at night (Fig. 1B). The mean $\mathrm{pH}$ values in the dense seagrass (LHHT) areas ranged from 8.15 during mid-afternoon to 7.68 near dawn. These $\mathrm{pH}$ values corresponded to a
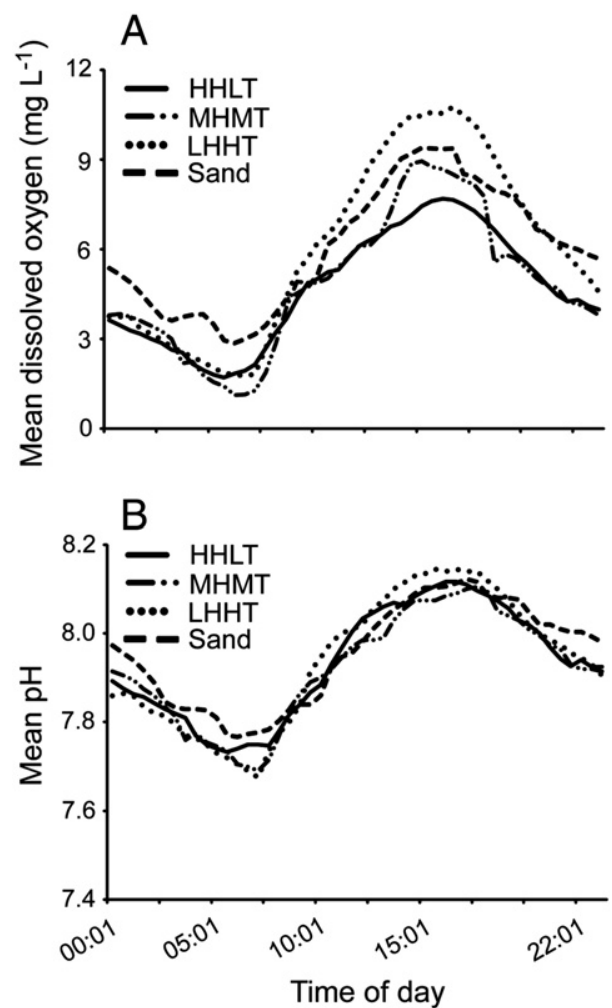

Fig. 1. Temporal variation among treatments for A) mean dissolved oxygen concentrations ( $\mathrm{mg} \mathrm{L}^{-1}$ ) over a 24 -hour cycle and B) mean $\mathrm{pH}$ over a 24 -h cycle. HHLT = high density of Halimeda incrassata and low density of Thalassia testudinum; MHMT = medium density of $H$. incrassata and medium density of $T$. testudinum; LHHT $=$ low density of $H$. incrassata and high density of $T$. testudinum; Sand $=$ unvegetated sediment. 
Table 1

Results of PERMANOVA analyses based on environmental data. $\left[\mathrm{H}^{+}\right]=$hydrogen ion concentrations; $\mathrm{Tr}=$ treatment; Err $=$ error.

\begin{tabular}{|c|c|c|c|c|c|c|c|}
\hline Parameter & Factor & df & SS & MS & Pseudo-F & $\mathrm{p}$ & $\begin{array}{l}\text { Unique } \\
\text { permutations }\end{array}$ \\
\hline \multirow[t]{2}{*}{ All environmental data } & $\operatorname{Tr}$ & 3 & 528.3 & 176.1 & 1.66 & 0.068 & 918 \\
\hline & Err & 6 & 637.9 & 106.3 & & & \\
\hline \multirow[t]{2}{*}{$24 \mathrm{~h}\left[\mathrm{H}^{+}\right]$} & $\operatorname{Tr}$ & 3 & 55.0 & 18.3 & 0.47 & 0.908 & 921 \\
\hline & Err & 6 & 31.4 & 0.2 & & & \\
\hline \multirow[t]{2}{*}{ Daytime $\left[\mathrm{H}^{+}\right]$} & $\operatorname{Tr}$ & 3 & 53.8 & 17.9 & 0.89 & 0.562 & 922 \\
\hline & Err & 6 & 120.2 & 20.0 & & & \\
\hline
\end{tabular}

mean $\left[\mathrm{H}^{+}\right]$of $7.22 \mathrm{nmol} \mathrm{L} \mathrm{L}^{-1}$ seawater during the day, with nearly a tripling to $21.17 \mathrm{nmol} \mathrm{L}^{-1}$ seawater over the course of approximately $12 \mathrm{~h}$. In addition, $\mathrm{pH}$ for the LHHT treatment increased faster during the morning, which resulted in a slightly higher value for that treatment by about 10:00 AM (Fig. 1B).

Although DO concentrations and $\mathrm{pH}$ values exhibited pronounced diel variation, PERMANOVAs indicated that the time series for all environmental variables and hydrogen ion concentrations did not differ significantly among treatments (Table 1 ). Thus, we consider macrophytes at all sites to be subjected to similar temporal variation in physical and chemical factors, i.e., the water in Grape Tree Bay was relatively well mixed.

\subsection{Initial biomass and rates of production}

Initial dry weights for shoots of $T$. testudinum and thalli of $H$. incrassata were homoscedastic after log-transformation, and normality was improved (Table 2 ). Dry weights of $T$. testudinum shoots were significantly different among treatments, with due regard for significant differences among sites (Table 2). Post-hoc comparisons showed that mean initial dry weights increased by $1.8 \times$ with each increase in the density of seagrass (Fig. 2A). In contrast, initial dry weights of $H$. incrassata thalli varied by up to $2.6 \times$ among sites, with no statistically significant pattern related to treatment (Table 2, Fig. 2B).

Rates of $T$. testudinum production ( $\mathrm{mg} \mathrm{DW}_{\text {shoot }}{ }^{-1} \mathrm{~d}^{-1}$ ) were homoscedastic and normal when log-transformed (Table 2). Production rates differed significantly among treatments and also among sites (Table 2). Variation among treatments was of greater ecological interest, and post-hoc, pairwise comparisons showed that T. testudinum production increased with increasing shoot density (Fig. 3A). Shoots in the treatment with the highest density (LHHT) were $\sim 2.4 \times$ more productive than shoots in treatment with the lowest density (Fig. 3A).

For $H$. incrassata, rates of production ( $m g$ DW thallus ${ }^{-1} \mathrm{~d}^{-1}$ ) in terms of both organic material and $\mathrm{CaCO}_{3}$ were homoscedastic and normal (Table 2) after log-transformation. Rates of production for organic and inorganic material differed among treatments (Table 2). The

Table 2

Results of ANOVAs for Thalassia testudinum (T. t) and Halimeda incrassata (H. i).

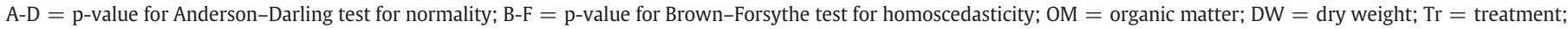
$\mathrm{Si}(\mathrm{Tr})=$ site within treatment; Err = error.

\begin{tabular}{|c|c|c|c|c|c|c|c|c|c|}
\hline Species & Metric & $A-D$ & $\mathrm{~B}-\mathrm{F}$ & Factor & df & SS & MS & $\mathrm{F}$ & $\mathrm{p}$ \\
\hline \multirow[t]{3}{*}{ T. $t$} & mg DW initial & $<0.01$ & $>0.25$ & $\operatorname{Tr}$ & 2 & 18.40 & 9.20 & 9.41 & 0.014 \\
\hline & (shoot) & & & $\mathrm{Si}(\mathrm{Tr})$ & 6 & 5.89 & 0.98 & 16.69 & $<0.001$ \\
\hline & & & & Err & 333 & 19.60 & 0.06 & & \\
\hline \multirow[t]{3}{*}{ H. $i$} & mg DW initial & $<0.01$ & $>0.25$ & $\operatorname{Tr}$ & 2 & 1.01 & 0.50 & 1.79 & 0.242 \\
\hline & (thallus) & & & $\mathrm{Si}(\mathrm{Tr})$ & 6 & 1.86 & 0.31 & 4.12 & 0.001 \\
\hline & & & & Err & 163 & 12.26 & 0.08 & & \\
\hline \multirow[t]{3}{*}{ T. $t$} & mg DW shoot ${ }^{-1} \mathrm{~d}^{-1}$ & $>0.25$ & 0.67 & $\operatorname{Tr}$ & 2 & 2.95 & 1.47 & 8.16 & 0.019 \\
\hline & $(\mathrm{OM})$ & & & $\mathrm{Si}(\operatorname{Tr})$ & 6 & 1.08 & 0.18 & 8.96 & $<0.001$ \\
\hline & & & & Err & 331 & 6.68 & 0.02 & & \\
\hline \multirow[t]{6}{*}{ H. $i$} & mg DW thallus ${ }^{-1} \mathrm{~d}^{-1}$ & 0.22 & 0.31 & $\operatorname{Tr}$ & 2 & 2.73 & 1.36 & 7.15 & 0.026 \\
\hline & $(\mathrm{OM})$ & & & $\mathrm{Si}(\operatorname{Tr})$ & 6 & 1.15 & 0.19 & 2.78 & 0.013 \\
\hline & & & & Err & 179 & 12.29 & 0.07 & & \\
\hline & mg DW thallus ${ }^{-1} \mathrm{~d}^{-1}$ & $>0.25$ & 0.06 & $\operatorname{Tr}$ & 2 & 3.78 & 1.89 & 9.17 & 0.015 \\
\hline & $\left(\mathrm{CaCO}_{3}\right)$ & & & $\mathrm{Si}(\operatorname{Tr})$ & 6 & 1.24 & 0.21 & 1.76 & 0.110 \\
\hline & & & & Err & 179 & 21.00 & 0.12 & & \\
\hline \multirow[t]{3}{*}{ T. $t$} & mg DW new:mg DW old $d^{-1}$ & $<0.01$ & 0.02 & $\operatorname{Tr}$ & 2 & 0.85 & 0.43 & 3.75 & 0.088 \\
\hline & (shoot) & & & $\mathrm{Si}(\operatorname{Tr})$ & 6 & 0.68 & 0.11 & 1.68 & 0.124 \\
\hline & & & & Err & 334 & 22.69 & 0.07 & & \\
\hline \multirow[t]{3}{*}{ H. $i$} & mg DW new:mg DW old $\mathrm{d}^{-1}$ & 0.02 & $>0.25$ & $\operatorname{Tr}$ & 2 & $8.0 \times 10^{-5}$ & $4.0 \times 10^{-5}$ & 0.48 & 0.635 \\
\hline & $(\mathrm{OM})$ & & & $\mathrm{Si}(\operatorname{Tr})$ & 6 & $5.0 \times 10^{-4}$ & $8.4 \times 10^{-5}$ & 1.07 & 0.380 \\
\hline & & & & Err & 159 & $1.2 \times 10^{-2}$ & $7.8 \times 10^{-5}$ & & \\
\hline \multirow{2}{*}{ T. $t$} & mg DW $m^{-2} d^{-1}$ & $>0.25$ & 0.65 & $\operatorname{Tr}$ & 2 & $2.3 \times 10^{7}$ & $1.2 \times 10^{7}$ & 158.52 & $<0.001$ \\
\hline & $(\mathrm{OM})$ & & & Error & 6 & $4.4 \times 10^{5}$ & $7.4 \times 10^{4}$ & & \\
\hline \multirow[t]{13}{*}{ H. $i$} & mg DW $\mathrm{m}^{-2} \mathrm{~d}^{-1}$ & 0.14 & 0.74 & $\operatorname{Tr}$ & 2 & $4.0 \times 10^{5}$ & $2.0 \times 10^{5}$ & 311.31 & $<0.001$ \\
\hline & $(\mathrm{OM})$ & & & Error & 6 & $3.9 \times 10^{3}$ & $6.4 \times 10^{2}$ & & \\
\hline & mg DW $\mathrm{m}^{-2} \mathrm{~d}^{-1}$ & 0.19 & 0.71 & $\operatorname{Tr}$ & 2 & $1.2 \times 10^{6}$ & $5.9 \times 10^{5}$ & 335.63 & $<0.001$ \\
\hline & $\left(\mathrm{CaCO}_{3}\right)$ & & & Error & 6 & $1.1 \times 10^{4}$ & $1.8 \times 10^{3}$ & & \\
\hline & $\mathrm{CaCO}_{3}: \mathrm{OM}$ & $>0.25$ & 0.41 & $\operatorname{Tr}$ & 2 & 0.46 & 0.23 & 0.34 & 0.723 \\
\hline & (new growth) & & & $\mathrm{Si}(\operatorname{Tr})$ & 6 & 4.01 & 0.67 & 3.35 & 0.004 \\
\hline & & & & Err & 157 & 31.38 & 0.20 & & \\
\hline & $\mathrm{CaCO}_{3}: \mathrm{OM}$ & 0.21 & $<0.01$ & $\operatorname{Tr}$ & 2 & 0.56 & 0.280 & 14.71 & 0.005 \\
\hline & (whole thallus) & & & $\mathrm{Si}(\mathrm{Tr})$ & 6 & 0.11 & 0.020 & 3.79 & 0.001 \\
\hline & & & & Err & 180 & 0.90 & 0.005 & & \\
\hline & $\mathrm{CaCO}_{3}$ :thallus & $>0.25$ & 0.06 & $\operatorname{Tr}$ & 2 & 0.15 & 0.070 & 12.18 & 0.008 \\
\hline & & & & $\mathrm{Si}(\operatorname{Tr})$ & 6 & 0.04 & 0.010 & 4.16 & $<0.001$ \\
\hline & & & & Err & 180 & 0.27 & 0.001 & & \\
\hline
\end{tabular}




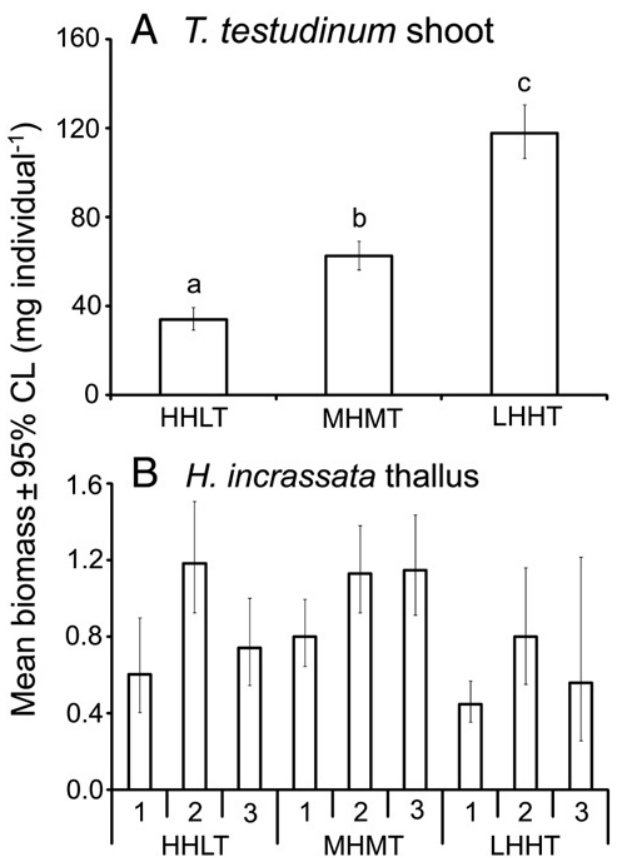

Fig. 2. Back-transformed mean initial biomass of individual A) Thalassia testudinum shoots and B) thalli of Halimeda incrassata. Error bars indicate 95\% confidence limits (CL). Differing letters above columns indicate statistically significant differences among treatments for the appropriate metric as determined by pairwise follow-up tests. HHLT = high density of $H$. incrassata and low density of $T$. testudinum; MHMT = medium density of $H$. incrassata and medium density of T. testudinum; LHHT = low density of $H$. incrassata and high density of $T$. testudinum; $1-3=$ sites within treatments.

rate at which organic matter was produced also varied significantly among sites within treatments (Table 2), but these results were not explored further because variability at this spatial scale was of less ecological interest. Thalli produced organic matter and $\mathrm{CaCO}_{3}$ at statistically equal rates in treatments with low and intermediate densities of $T$. testudinum (HHLT and MHMT), and thalli produced significantly less of both types of carbon $\mathrm{d}^{-1}$ at sites where $T$. testudinum was most dense (LHHT) according to post-hoc, pairwise comparisons (Fig. 3B, C). In fact, thalli in the LHHT treatment were approximately $3.5 \times$ less productive than thalli in other treatments (Fig. 3B, C).

Standardized rates of production for T. testudinum were homoscedastic following log-transformation, but they remained non-normal (Table 2). Nevertheless, standardized rates of production were not significantly different among treatments or sites, which represented a robust result (Table 2). The mean standardized rates of production for shoots in low density (HHLT) and medium density (MHMT) seagrass treatments were nearly equal and approximately $1.3 \times$ the mean rate for shoots in high density seagrass treatments (LHHT; Fig. 4A).

Standardized rates of production of organic matter for $\mathrm{H}$. incrassata were homoscedastic and normal without transformation (Table 2). These rates did not differ significantly among treatments or sites (Table 2, Fig. 4B). The mean standardized rates of production of organic matter in the low (HHLT) and medium (MHMT) density seagrass treatments were nearly equal and approximately $1.2 \times$ the mean rate for thalli in the high density T. testudinum treatment (LHHT; Fig. 4B).

When rates of production for individual shoots and thalli were scaled to $1 \mathrm{~m}^{2}$ using the mean number of individuals $\mathrm{m}^{-2}$ in a given treatment, the resulting rates of areal production were homoscedastic and normal (Table 2). Areal production was significantly different among treatments for $T$. testudinum shoots, $H$. incrassata organic matter and $\mathrm{H}$. incrassata $\mathrm{CaCO}_{3}$ content (Table 2). For T. testudinum, posthoc multiple comparisons showed sites with dense seagrass yielded significantly greater areal production and production decreased significantly with decreasing density (Fig. 5A). Similarly, rates of areal production of organic matter and $\mathrm{CaCO}_{3}$ for $\mathrm{H}$. incrassata decreased

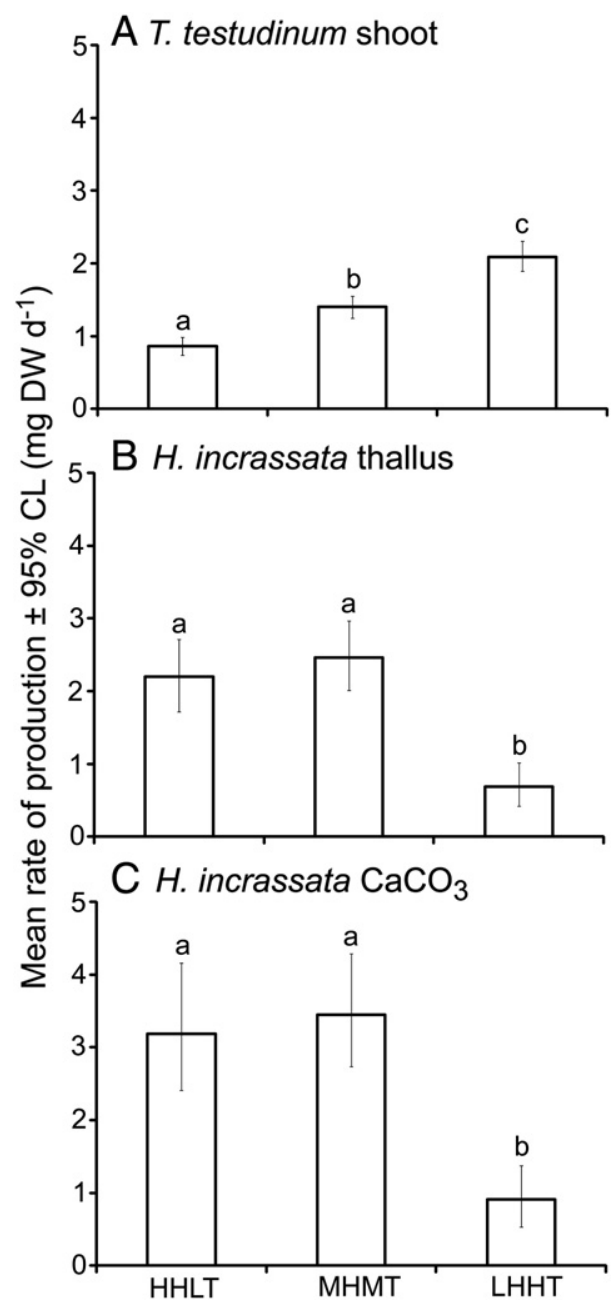

Fig. 3. Back-transformed mean rates of production per individual shoot or thallus for A) Thalassia testudinum shoots, B) organic matter in thalli of Halimeda incrassata and C) calcium carbonate $\left(\mathrm{CaCO}_{3}\right)$ in thalli of $\mathrm{H}$. incrassata. Error bars indicate $95 \%$ confidence limits (CL). Differing letters above columns indicate statistically significant differences among treatments for the appropriate metric as determined by pairwise follow-up tests. HHLT = high density of $H$. incrassata and low density of $T$. testudinum; MHMT $=$ medium density of $H$. incrassata and medium density of $T$. testudinum; LHHT $=$ low density of $H$. incrassata and high density of $T$. testudinum.

as density of this macrophyte decreased (Fig. 5B and C). Overall, mean rates of areal production for $T$. testudinum and $H$. incrassata spanned an order of magnitude.

\subsection{Calcification}

Ratios of $\mathrm{CaCO}_{3}$ to organic material $\left(\mathrm{CaCO}_{3}: \mathrm{OM}\right)$ in the new growth of $H$. incrassata were normal and homoscedastic (Table 2) without transformation. These ratios were not significantly different among treatments, although there was significant variation among sites within treatments (Table 2). Thus, the $\mathrm{CaCO}_{3}$ content of new plates varied among thalli, but it did not differ consistently among treatments (Fig. 6A).

Ratios of $\mathrm{CaCO}_{3}$ : OM for whole thalli were normal after logtransformation, but the data remained heteroscedastic so the results of the ANOVA were interpreted cautiously (Table 2). Ratios of $\mathrm{CaCO}_{3}: \mathrm{OM}$ in whole thalli differed significantly among treatments and among sites within treatments (Table 2). Post-hoc multiple comparisons indicated that thalli in the sites with the densest seagrass (LHHT) had $1.4-1.5 \times$ higher $\mathrm{CaCO}_{3}: \mathrm{OM}$ ratios than thalli in other treatments (HHLT and MHMT), which indicated that relatively more calcification had occurred (Fig. 6B). 


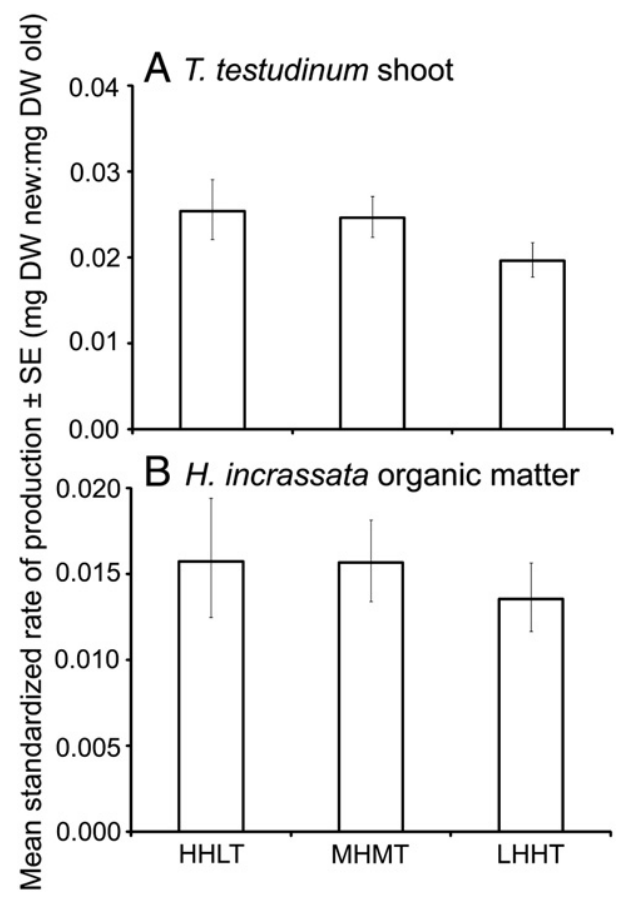

Fig. 4. Mean standardized rates of production for A) shoots of Thalassia testudinum, B) organic matter in thalli of Halimeda incrassata. Error bars indicate standard errors (SE). HHLT $=$ high density of $H$. incrassata and low density of T. testudinum; MHMT = medium density of $H$. incrassata and medium density of $T$. testudinum; LHHT $=$ low density of $H$. incrassata and high density of $T$. testudinum.

The proportions of whole thalli comprising $\mathrm{CaCO}_{3}$ were normal and homoscedastic after arcsine-transformation (Table 2). Thalli from different treatments exhibited significant differences in their $\mathrm{CaCO}_{3}$ content, and thalli from different sites within treatments also differed significantly (Table 2). Post-hoc multiple comparison tests, with Tukey-Kramer adjustments, showed that thalli in the dense seagrass treatment contained proportionately more $\mathrm{CaCO}_{3}$ than thalli in other treatments. Thalli growing in dense seagrass (mean and $95 \%$ confidence limits $=0.85$ and $0.84-0.86$ ) were $5-6 \%$ more calcified than thalli growing in areas with medium density $(0.80$ and $0.79-0.81)$ or low density $(0.79$ and $0.78-0.80)$ seagrass.

\section{Discussion}

Predicting the potential impact of ocean acidification on organisms that rely on $\mathrm{CaCO}_{3}$ requires an understanding of their responses to local variations in factors affecting the stoichiometry of the carbonic acid system and the dynamics of physiological processes governing uptake and sequestration of carbon. For example, seawater chemistry in shallow, tropical lagoons tends to vary across 24 -h periods because rates of photosynthesis and respiration vary. Furthermore, the physiologies of seagrasses and sympatric macroalgae are affected by positive and negative ecological interactions. By measuring in situ rates of production and calcification at sites with different densities of T. testudinum and $H$. incrassata, this study contributes insights into the relative importance of biotic and abiotic factors at the local scale.

Interspecific and intraspecific biotic interactions for T. testudinum and $H$. incrassata include facilitation and competition. $H$. incrassata and other rhizophytic algae can successfully colonize and persist in unstable, nutrient-poor sediments due to their ability to anchor themselves and more efficiently garner scarce nutrients (Demes et al., 2010; Hillis-Colinvaux, 1980; Williams, 1981). Thus, rhizophytic algae can facilitate colonization and growth of $T$. testudinum and other seagrasses by stabilizing sediments, increasing the accumulation of nutrients in the sediment as thalli decompose, and reducing the release of nutrients into the water column by protecting sediments from

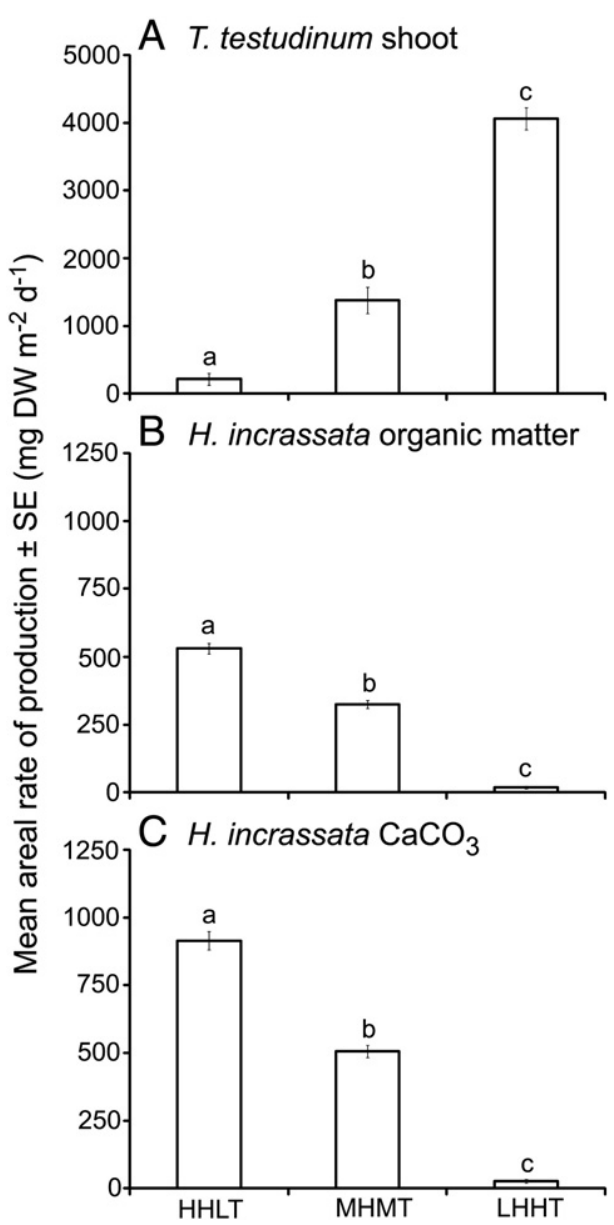

Fig. 5. Mean areal rates of production for A) Thalassia testudinum shoots, B) organic matter in thalli of Halimeda incrassata and $\mathrm{C}$ ) calcium carbonate $\left(\mathrm{CaCO}_{3}\right)$ in thalli of H. incrassata. Error bars indicate standard errors (SE). Differing letters above columns indicate statistically significant differences among treatments for the appropriate metric as determined by pairwise follow-up tests. Note the difference in scaling of y-axes. HHLT $=$ high density of $H$. incrassata and low density of $T$. testudinum; MHMT $=$ medium density of $H$. incrassata and medium density of $T$. testudinum; LHHT $=$ low density of $H$. incrassata and high density of $T$. testudinum.

disturbance (McRoy and McMillan, 1977; Orth, 1977; Williams, 1984, 1990). The high density H. incrassata treatments illustrated potential interactions in the early stages of colonization, with $T$. testudinum shoots being smaller and less productive on an individual or areal basis. After colonization and establishment by seagrass, calcifying macroalgae often decrease in abundance because seagrasses tend to be superior competitors for space, light or nutrients. In fact, T. testudinum represents a particularly strong competitor, and it dominates many tropical seagrass beds via exploitative competition (Williams, 1987, 1990; Zieman and Wetzel, 1980). For example, T. testudinum has been shown to compete for nitrogen with $H$. incrassata when present at densities of $400-800$ shoots $\mathrm{m}^{-2}$ (Davis and Fourqurean, 2001), and T. testudinum densities as low as 200 shoots $\mathrm{m}^{-2}$ were associated with a decline in the abundance of rhizophytic algae (Williams, 1990). In the present study, no significant negative effect on $H$. incrassata production was observed at seagrass densities up to 1312 shoots $\mathrm{m}^{-2}$ (i.e., HHLT and MHMT treatments). However, rates of production measured on an individual or areal basis were reduced at seagrass densities at or above 1650 shoots $\mathrm{m}^{-2}$ (i.e., LHHT treatment), suggesting that some level of competition (sensu Davis and Fourqurean, 2001) occurs at high seagrass densities in Grape Tree Bay. In addition, standardized rates of production of organic matter were lowest for $H$. incrassata amid dense $T$. testudinum. In contrast, standardized rates of production for $T$. testudinum remained relatively high at sites with high and 


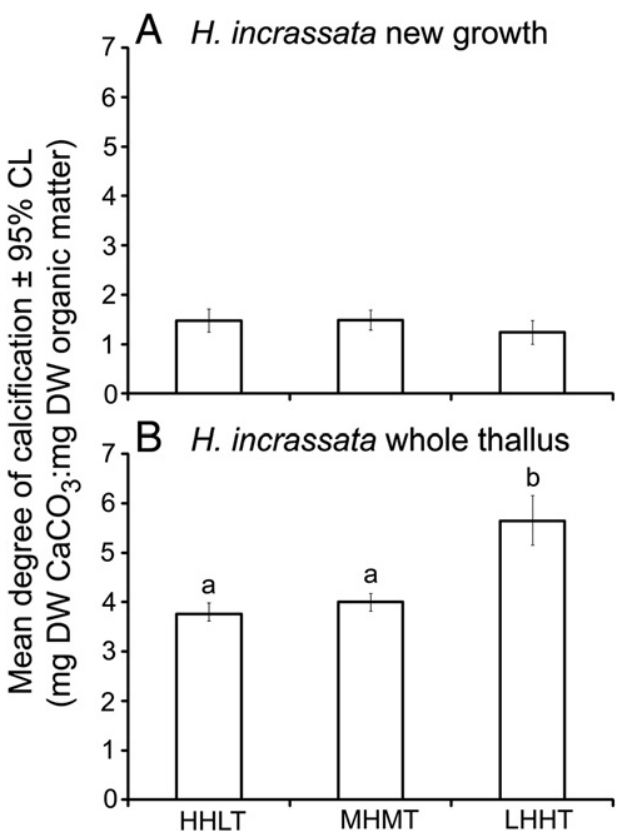

Fig. 6. Mean degrees of calcification (ratio of calcium carbonate $\left[\mathrm{CaCO}_{3}\right]$ to organic matter $[\mathrm{OM}]$ ) for A) new growth and B) whole thalli of Halimeda incrassata. Error bars indicate $95 \%$ confidence limits (CL). Differing letters above columns indicate statistically significant differences among treatments for the appropriate metric as determined by pairwise follow-up tests. HHLT = high density of $H$. incrassata and low density of Thalassia testudinum; MHMT = medium density of $H$. incrassata and medium density of T. testudinum; LHHT = low density of H. incrassata and high density of T. testudinum.

medium densities of $H$. incrassata, which indicated no significant effect of interspecific competition and presaged eventual dominance by the seagrass. Standardized rates of production also yielded little evidence of intraspecific competition for $T$. testudinum and $H$. incrassata because they varied by only $1.3-1.4 \times$ when measured at sites where densities of conspecifics varied by 23-39×. Overall, the data indicated that biotic interactions, i.e., interspecific competition, could affect the dynamics of $\mathrm{CaCO}_{3}$ production by $\mathrm{H}$. incrassata at scales similar to Grape Tree Bay. Given light regimes in clear, shallow, tropical waters, this interspecific competition is likely to be for nutrients rather than light (Davis and Fourqurean, 2001).

As thalli of Halimeda spp. grow, they produce both organic matter and $\mathrm{CaCO}_{3}$, where production of $\mathrm{CaCO}_{3}$ is driven by photosynthesis in the thallus. For example, Jensen et al. (1985) reported that $77 \%$ of the variation in calcification of Halimeda copiosa, $\mathrm{H}$. cryptica, $\mathrm{H}$. discoidea, and $H$. lacrimosa could be explained by variation in the rate of photosynthesis. In addition, both net carbonate accretion and carbonate dissolution were reduced or absent in the dark (Borowitzka and Larkum, 1976a,b,c, 1977; de Beer and Larkum, 2001; Goreau, 1963), which further demonstrates the link between calcification and photosynthesis in Halimeda spp. Thus, ratios of $\mathrm{CaCO}_{3}$ to organic matter (OM) yield insights into the dynamics of calcification.

When only new growth of $\mathrm{H}$. incrassata was considered, $\mathrm{CaCO}_{3}: \mathrm{OM}$ ratios were not significantly different regardless of the density of $T$. testudinum surrounding the algae, with the range of ratios across varying densities of seagrass being 0.25 . In contrast, the maximum difference among $\mathrm{CaCO}_{3}: \mathrm{OM}$ ratios for whole thalli, i.e., ratios including older plates, was 1.88 , which is $7 \times$ the range observed for new growth, suggesting that continued $\mathrm{CaCO}_{3}$ accumulation varied significantly among sites with different densities of seagrass. In fact, the highest $\mathrm{CaCO}_{3}: \mathrm{OM}$ ratio was recorded for $\mathrm{H}$. incrassata growing among the highest density of $T$. testudinum. In combination, these results indicate that new $H$. incrassata plates, i.e., those less than $7 \mathrm{~d}$ old, are produced with a relatively constant $\mathrm{CaCO}_{3}$ : $\mathrm{OM}$ ratio and $\mathrm{CaCO}_{3}$ content continues to increase in older plates, especially for thalli surrounded by dense seagrass (LHHT). Previously, van Tussenbroek and van Dijk (2007) found that mature, basal plates of $H$. incrassata were heavier than newly produced plates, and other studies have documented an increase in $\mathrm{CaCO}_{3}$ content as plates age (Borowitzka and Larkum, 1976a, 1977; Multer, 1988). This is the first study to report that accumulation of $\mathrm{CaCO}_{3}$ may depend on the density of surrounding seagrasses. Competition for nutrients represents a potential cause of increased calcification if thalli amid dense seagrass continue to photosynthesize to support the respiratory demands of existing tissue because $\mathrm{CaCO}_{3}$ will be produced as a byproduct and addition of new tissue will be limited by a lack of nutrients.

Abiotic influences on calcification have been reported, with seagrasses or fleshy macroalgae creating seawater chemistry favorable to algal and coral calcification (Anthony et al., 2011; Kleypas et al., 2011; Semesi et al., 2009a,b; Unsworth et al., 2012). Most of these results were obtained under naturally (Kleypas et al., 2011), artificially (Anthony et al., 2011; Semesi et al., 2009a,b) or modeled (Unsworth et al., 2012) low mixing conditions (high water residence time). Based on measurements of water chemistry at a larger spatial scale, Manzello et al. (2012) suggested seagrasses in the Florida Reef Tract may create refugia from ocean acidification for nearby reefs due to a seagrass-mediated decrease in total carbon dioxide concentrations in inshore environments. In contrast, data for Grape Tree Bay suggest that such abiotic effects may not be significant at smaller spatial scales because 1 ) in even moderately well-mixed conditions, the $\mathrm{pH}$ regime in the seagrass canopy did not differ significantly from unvegetated areas and 2) calcification of new tissue did not vary significantly across the density gradient created by $T$. testudinum. Moreover, the rates of production and consequent areal production of $\mathrm{CaCO}_{3}$ were significantly lower in dense $T$. testudinum beds, which indicates that biotic interaction between these macrophytes, i.e., competition, represents a key factor. Further evidence for physiological mediation of direct effects from abiotic conditions is provided by inconsistent responses to increased partial pressures of carbon dioxide for several Halimeda spp. (e.g., Comeau et al., 2013; Price et al., 2011; Ries et al., 2009), buffering from external $\mathrm{pH}$ because calcification occurs in intercellular spaces within thalli, and a tight link between photosynthesis and calcification (de Beer and Larkum, 2001; Jensen et al., 1985).

Collectively, the results presented here suggest that enhancement of calcification likely will depend on water residence time (Anthony et al., 2011; Kleypas et al., 2011; Unsworth et al., 2012) and ecological processes that affect both the abundances of macrophytes and their ability to garner resources, such as competition and succession (Davis and Fourqurean, 2001; van Tussenbroek and van Dijk, 2007; Williams, 1990). These results also suggest that a combination of manipulative and mensurative experiments is needed to elucidate the outcomes of positive and negative interactions between seagrasses, like $T$. testudinum, and rhizophytic, calcareous algae, like $H$. incrassata, in oceans that are becoming increasingly acidic. Future studies should compare calcification and $\mathrm{pH}$ regimes at larger spatial scales (i.e., across multiple lagoons) to assess the strength of the seagrassmediated effect in different hydrodynamic conditions and habitat mosaics. Data on local hydrodynamics and diel variations in seawater chemistry also will be important in furthering our understanding of biotic and abiotic influences on calcium carbonate production.

\section{Acknowledgments}

We thank E. Phlips and J. Fourqurean for their insights and comments on the draft manuscript. We appreciate logistical support provided by M. Edwards, N. van Niekerk, S. Notestein, D. Saindon, and J. Frost. We also thank the staff of the Little Cayman Research Center for additional logistical support during the course of the study. Finally, we thank the Cayman Islands Department of the Environment for their support of this project. [SS] 


\section{References}

Anderson, R., Gorley, R.N., Clarke, K.R., 2008. PERMANOVA + for PRIMER: Guide to Software and Statistical Methods. PRIMER-E, Plymouth, UK.

Anthony, K.R.N., Kleypas, J.A., Gattuso, J., 2011. Coral reefs modify their seawater carbon chemistry - implications for impacts of ocean acidification. Glob. Chang. Biol. 17, 3655-3666.

Borowitzka, M.A., Larkum, A.W.D., 1976a. Calcification in the green alga Halimeda. II. Exchange of $\mathrm{Ca}^{2+}$ and occurrence of age gradients in calcification and photosynthesis. J. Exp. Bot. 27, 864-878.

Borowitzka, M.A., Larkum, A.W.D., 1976b. Calcification in the green alga Halimeda. III. Sources of inorganic carbon for photosynthesis and calcification and a model of mechanism of calcification. J. Exp. Bot. 27, 879-893.

Borowitzka, M.A., Larkum, A.W.D., 1976c. Calcification in the green alga Halimeda. IV. Action of metabolic inhibitors on photosynthesis and calcification. J. Exp. Bot. 27, 894-907.

Borowitzka, M.A., Larkum, A.W.D., 1977. Calcification in the green alga Halimeda. I. Ultrastructure study of thallus development. J. Phycol. 13, 6-16.

Byers, S.C., Mills, E.L., Stewart, P.L., 1978. Comparison of methods of determining organic carbon in marine sediments, with suggestions for a standard method. Hydrobiologia 58, 43-47.

Comeau, S., Edmunds, P.J., Spindel, N.B., Carpenter, R.C., 2013. The responses of eight coral reef calcifiers to increasing partial pressure of $\mathrm{CO}_{2}$ do not exhibit a tipping point. Limnol. Oceanogr. 58, 388-398.

Corlett, H., Jones, B., 2007. Epiphyte communities on Thalassia testudinum from Grand Cayman, British West Indies: their composition, structure, and contribution to lagoonal sediments. Sediment. Geol. 194, 245-262.

Dahlgren, C., Marr, J., 2004. Back reef systems: important but overlooked components of tropical marine ecosystems. Bull. Mar. Sci. 75, 145-152.

Davis, B.C., Fourqurean, J.W., 2001. Competition between the tropical alga, Halimeda incrassata, and the seagrass, Thalassia testudinum. Aquat. Bot. 71, 217-232.

de Beer, D., Larkum, A.W.D., 2001. Photosynthesis and calcification in the calcifying algae Halimeda discoidea studied with microsensors. Plant Cell Environ. 24, 1209-1217.

Demes, K.W., Littler, M.M., Littler, D.S., 2010. Comparative phosphate acquisition in giant-celled rhizophytic algae (Bryopsidales, Chlorophyta): fleshy vs. calcified forms. Aquat. Bot. 92, 157-160.

Doney, S.C., Ruckelshaus, M., Duffy, J.E., Barry, J.P., Chan, F., English, C.A., Galindo, H.M., Grebmeier, J.M., Hollowed, A.B., Knowlton, N., Polovina, J., Rabalais, N.N., Sydeman, W.J., Talley, L.D., 2012. Climate change impacts on marine ecosystems. Annu. Rev. Mar. Sci. 4, 11-37.

Duarte, C.M., Marba, N., Gacia, E., Fourqurean, J.W., Beggins, J., Barron, C., Apostolaki, E.T., 2010. Seagrass community metabolism: assessing the carbon sink capacity of seagrass meadows. Global Biogeochem. Cycles 24, GB4032-GB.

Eisler, R., 2010. Compendium of Trace Metals and Marine Biota Volume 1: Plants and Invertebrates. Elsevier, Oxford, U.K.

Fong, P., Paul, V.J., 2011. Coral reef algae. In: Dubinsky, Z., Stambler, N. (Eds.), Coral Reefs: An Ecosystem in Transition. Springer, Dordrecht, Netherlands, pp. 241-272.

Fourqurean, J.W., Duarte, C.M., Kennedy, H., Marba, N., Holmer, M., Mateo, M.A., Apostolaki, E.T., Kendrick, G.A., Krause-Jensen, D., McGlathery, K.J., Serrano, O., 2012. Seagrass ecosystems as a globally significant carbon stock. Nat. Geosci. 5, 505-509.

Freile, D., Milliman, J.D., Hillis, L., 1995. Leeward bank margin Halimeda meadows and draperies and their sedimentary importance on the western Great Bahama Bank slope. Coral Reefs 14, 27-33.

Goreau, T.F., 1963. Calcium carbonate deposition by coralline algae and corals in relation to their roles as reef-builders. Annu. NY Acad. Sci. 109, 127-167.

Guinotte, J.M., Fabry, V.J., 2008. Ocean acidification and its potential effects on marine ecosystems. Annu. NY Acad. Sci. 1134, 320-342.

Hillis-Colinvaux, L., 1980. Ecology and taxonomy of Halimeda: primary producer of coral reefs. Adv. Mar. Biol. 17, 1-327.

Hirota, J., Szyper, J.P., 1975. Separation of total particulate carbon into inorganic and organic components. Limnol. Oceanogr. 20, 896-900.

Hoegh-Guldberg, O., Mumby, P.J., Hooten, A.J., Steneck, R.S., Greenfield, P., Gomez, E., Harvell, C.D., Sale, P.F., Edwards, A.J., Caldeira, K., Knowlton, N., Eakin, C.M., IglesiasPrieto, R., Muthiga, N., Bradbury, R.H., Dubi, A., Hatziolos, M.E., 2007. Coral reefs under rapid climate change and ocean acidification. Science 318, 1737-1742.

Jensen, P.R., Gibson, R.A., Littler, M.M., Littler, D.S., 1985. Photosynthesis and calcification in 4 deep-water Halimeda species (Chlorophyceae, Caulerpales). Deep-Sea Res. 32, 451-464.

Kleypas, J.A., Buddemeier, R.W., Archer, D., Gattuso, J.-P., Langdon, C., Opdyke, B.N., 1999. Geochemical consequences of increased atmospheric $\mathrm{CO}_{2}$ on coral reefs. Science $284,118-120$.

Kleypas, J.A., Anthony, K.R.N., Gattuso, J., 2011. Coral reefs modify their seawater carbon chemistry-case study from a barrier reef (Moorea, French Polynesia). Glob. Chang. Biol. 17, 3667-3678.

Kroeker, K.J., Kordas, R.L., Crim, R.N., Singh, G.G., 2010. Meta-analysis reveals negative yet variable effects of ocean acidification on marine organisms. Ecol. Lett. 13, 1419-1434.

Lee, D., Carpenter, S.J., 2001. Isotopic disequilibrium in marine calcareous algae. Chem. Geol. 172, 307-329.

Littler, M.M., 1976. Calcification and its role among the macroalgae. Micronesica 12, 27-41.

Littler, M.M., Littler, D.S., 1988. Structure and role of algae in tropical reef communities. In: Lembi, C.A., Waaland, J.R. (Eds.), Algae and Human Affairs. Cambridge University Press, Cambridge, pp. 29-55.
Littler, M.M., Littler, D.S., 1994. Tropical reefs as complex habitats for diverse macroalgae In: Lobban, C.S., Harrison, P.J. (Eds.), Seaweed Ecology and Physiology. Cambridge University Press, New York, pp. 72-75.

Mantyka, C.S., Bellwood, D.R., 2007. Macroalgal grazing selectivity among herbivorous coral reef fishes. Mar. Ecol. Prog. Ser. 352, 177-185.

Manzello, D.P., Enochs, I.C., Melo, N., Gledhill, D.K., Johns, E.M., 2012. Ocean acidification refugia of the Florida reef tract. PLoS One 7, e41715.

McClendon, J.F., 1917. Physical Chemistry of Vital Phenomena for Students and Investigators in the Biological and Medical Sciences. Princeton University Press, Princeton.

McClendon, J.F., 1918. On changes in the sea and their relation to organisms. Papers from the Department of Marine Biology. Carnegie Institution, Washington, pp. 213-259.

McRoy, C.P., McMillan, C., 1977. Production ecology and physiology of seagrasses. In: McRoy, C.P., Helfferich, C. (Eds.), Seagrass Ecosystems: A Scientific Perspective. Marcel Dekker, New York, pp. 53-87.

Milliman, J.D., Droxler, A.W., 1996. Neritic and pelagic carbonate sedimentation in the marine environment: ignorance is not bliss. Geol. Rundsch. 85, 496-504.

Multer, H.G., 1988. Growth rate, ultrastructure and sediment contribution of Halimeda incrassata and Halimeda monile, Nonsuch and Falmouth Bays, Antigua, WI. Coral Reefs 6, 179-186.

National Research Council, Committee on the Development of an Integrated Science Strategy for Ocean Acidification Monitoring, Research, and Impacts Assessment 2010. Ocean Acidification: A National Strategy to Meet the Challenges of a Changing Ocean. The National Academies Press, Washington, DC.

Nelson, W.A., 2009. Calcified macroalgae-critical to coastal ecosystems and vulnerable to change: a review. Mar. Freshw. Res. 60, 787-801.

Orth, R.J., 1977. Effect of nutrient enrichment on growth of eelgrass Zostera marina in Chesapeake Bay, Virginia, USA. Mar. Biol. 44, 187-194.

Overholtzer, K.L., Motta, P.J., 1999. Comparative resource use by juvenile parrotfishes in the Florida Keys. Mar. Ecol. Prog. Ser. 177, 177-187.

Palacios, S.L., Zimmerman, R.C., 2007. Response of eelgrass Zostera marina to $\mathrm{CO}_{2}$ enrichment: possible impacts of climate change and potential for remediation of coastal habitats. Mar. Ecol. Prog. Ser. 344, 1-13.

Price, N.N., Hamilton, S.L., Tootell, J.S., Smith, J.E., 2011. Species-specific consequences of ocean acidification for the calcareous tropical green algae Halimeda. Mar. Ecol. Prog. Ser. 440, 67-78.

Radar, L.F., Grimaldi, R.S., 1961. Chemical analysis for selected minor elements in Pierre shale. U. S. Geol. Surv. Prof. Pap. 391-A (45 pp.)

Ries, J.B., Cohen, A.L., McCorkle, D.C., 2009. Marine calcifiers exhibit mixed responses to $\mathrm{CO}_{2}$-induced ocean acidification. Geology 37, 1131-1134.

Roberts, A.A., Palacas, J.G., Frost, I.C., 1973. Determination of organic carbon in modern carbonate sediments. J. Sediment. Petrol. 43, 1157-1159.

Semesi, I.S., Beer, S., Bjork, M., 2009a. Seagrass photosynthesis controls rates of calcification and photosynthesis of calcareous macroalgae in a tropical seagrass meadow. Mar. Ecol. Prog. Ser. 382, 41-47.

Semesi, I.S., Kangwe, J., Bjork, M., 2009b. Alterations in seawater $\mathrm{pH}$ and $\mathrm{CO}_{2}$ affect calcification and photosynthesis in the tropical coralline alga, Hydrolithon sp. (Rhodophyta). Estuar. Coast. Shelf Sci. 84, 337-341.

Skirrow, G., Whitfield, M., 1975. Effect of increases in atmospheric carbon dioxide content on carbonate ion concentration of surface ocean water at $25^{\circ} \mathrm{C}$. Limnol Oceanogr. 20, 103-108.

Unsworth, R.K.F., Collier, C.J., Henderson, G.M., McKenzie, L.J., 2012. Tropical seagrass meadows modify seawater carbon chemistry: implications for coral reefs impacted by ocean acidification. Environ. Res. Lett. 7, 024026.

van Tussenbroek, B.I., van Dijk, J.K., 2007. Spatial and temporal variability in biomass and production of psammophytic Halimeda incrassata (Bryopsidales, Chlorophyta) in a Caribbean reef lagoon. J. Phycol. 43, 69-77.

Vroom, P.S., Smith, C.M., Coyer, J.A., Walters, L.J., Hunter, C.L., Beach, K.S., Smith, J.E., 2003. Field biology of Halimeda tuna (Bryopsidales, Chlorophyta) across a depth gradient: comparative growth, survivorship, recruitment, and reproduction. Hydrobiologia 501, 149-166.

Waycott, M., Duarte, C.M., Carruthers, T.J.B., Orth, R.J., Dennison, W.C., Olyarnik, S Calladine, A., Fourqurean, J.W., Heck Jr., K.L., Hughes, A.R., Kendrick, G.A., Kenworthy, W.J., Short, F.T., Williams, S.L., 2009. Accelerating loss of seagrasses across the globe threatens coastal ecosystems. Proc. Natl. Acad. Sci. 106, 12377-12381.

Wefer, G., 1980. Carbonate production by the algae Halimeda, Penicillus and Padina. Nature $285,323-324$.

Williams, S.L., 1981. Caulerpa cupressoides: the relationship of the uptake of sediment ammonium and of algal decomposition to seagrass bed colonization. Dissertation. University of Maryland, College Park, Maryland, USA.

Williams, S.L., 1984. Decomposition of the tropical macroalga Caulerpa cupressoides (West) C. Agardh: field and laboratory studies. J. Exp. Mar. Biol. Ecol. 80, 109-124.

Williams, S.L., 1987. Competition between the seagrasses Thalassia testudinum and Syringodium filiforme in a Caribbean lagoon. Mar. Ecol. Prog. Ser. 35, 91-98.

Williams, S.L., 1990. Experimental studies of Caribbean seagrass bed development. Ecol. Monogr. 60, 449-469.

Zieman, J.C., 1974. Methods for study of growth and production of turtle grass, Thalassia testudinum Konig. Aquaculture 4, 139-143.

Zieman, J.C., Wetzel, R.G., 1980. Productivity in seagrasses: methods and rates. In: Phillips, R.C., McRoy, C.P. (Eds.), Handbook of Seagrasses Biology: An Ecosystem Perspective. Garland STPM, New York, NY, pp. 87-116. 